\title{
Polymorphonuclear leucocytes in Crohn's disease and ulcerative proctocolitis: association between enhanced adherence to nylon fibre and disease variables
}

\author{
J CASON, C C AINLEY, R A WOLSTENCROFT, * R P H THOMPSON
}

\begin{abstract}
From The Gastrointestinal Laboratory and * Department of Immunology, The Rayne Institute, St Thomas's Hospital, London
\end{abstract}

SUMMARY The adherence of polymorphonuclear leucocytes (PMN) to nylon fibre was investigated in patients with Crohn's disease, ulcerative proctocolitis, and anorexia nervosa, and compared with changes of circulating PMNs, C reactive protein concentrations, erythrocyte sedimentation rates, and clinical assessment of disease activity. PMN adherence was in excess of the maximum value detected for healthy subjects in 14 of 25 patients with Crohn's disease and two of 10 with proctocolitis, but it was within the normal range for all eight with anorexia nervosa. High adherence in Crohn's disease, however, was not associated with quantitative or qualitative changes of PMN populations, absolute concentrations of $\mathrm{C}$ reactive protein, erythrocyte sedimentation rates, disease severity, drug regimens, malnutrition, or zinc deficiency. High PMN adherence in Crohn's disease may therefore reflect the activation in vivo of normal PMN by humoral factors.

Adherence of polymorphonuclear leucocytes (PMN) to vascular endothelium is an early event in the acute inflammatory response and may be examined in vitro by measuring the adherence of PMN to nylon fibre.' PMN from patients with various chronic inflammatory conditions, ${ }^{2-4}$ including inflammatory bowel disease, ${ }^{5}$ exhibit high adherence values, and this feature may be a useful indicator of acute episodes. The causes of enhanced PMN adherence in inflammatory bowel disease, however, are largely unknown. Humoral substances have been implicated ${ }^{5}$ and these may be acute phase proteins. Alternatively, high adhesiveness may be due to qualitative or quantitative disturbances ${ }^{6}$ of circulating PMN.

In this study PMN adherence to nylon fibre in Crohn's disease and ulcerative proctocolitis was examined and results were compared with changes of circulating PMN, C reactive protein (CRP) concentration, erythrocyte sedimentation rates (ESR), and clinical assessment of disease activity. Crohn's disease is often complicated by malnutrition ${ }^{7-9}$ and zinc deficiency, ${ }^{10} 1$ the effects of which on PMN adherence are also unknown. Accordingly, these factors were examined in patients with Crohn's disease or with ulcerative proctocolitis. A further group of patients with anorexia nervosa was studied to assess the effect of malnutrition on PMN adherence.

Accepted for publication 16 September 1987
It was anticipated that changes in PMN adherence might relate to features of an acute phase response or to the severity of inflammatory bowel disease, or both.

\section{Patients and methods}

All subjects fasted overnight and blood samples were taken between 08.00 and 11.00 am the following morning. Twenty five healthy subjects with a median age of 35 (range 21-67) years (14 males); eight women with anorexia nervosa (median age 22, range 19-25 years, one receiving chlorpromazine), and 41 patients with inflammatory bowel disease were studied. Not all of the subjects were investigated with respect to all variables.

Patients with inflammatory bowel disease were diagnosed from clinical, radiological, and histological evidence. Twenty nine (fifteen men) had Crohn's disease (median age 30, range 18-74 years) for periods of one to 24 years. Severity of disease was assessed by the Crohn's disease activity index, ${ }^{12}$ with scores in excess of 150 indicative of active disease: further clinical details are given in table 1 .

Twelve patients (six men) had ulcerative proctocolitis (median age 42, range 22-62 years). Of these, three had severe, one moderate to severe, five moderate, and one mild disease, and two were in remission, assessed by the method of Truelove and Witts. ${ }^{13}$ Three patients were receiving no treatment; 
Table 1 Clinical details of the patients with Crohn's disease

Site of disease:
Small intestine
Terminal ileum
Large intestine
Rectum
Anus

Drug regimen:
Prednisolone $(2 \cdot 5-15 \mathrm{mg} /$ day $)$
Sulphasalazine $(0 \cdot 5-1 \cdot 5 \mathrm{~g} /$ day $)$
Azathioprine $(150 \mathrm{mg} / \mathrm{day})$
Adrenocorticotrophic hormone (1 mg/week)
Indomethacin $(50 \mathrm{mg} / \mathrm{day})$
Codeine phosphate $(64 \mathrm{mg} /$ day $)$
Nil

Active disease:

(Active disease $=$ activity index greater than 150 ; values ranged from scores of 28 to 471 .) four, sulphasalazine $(0 \cdot 5-2 \cdot 0 \mathrm{~g} /$ day $)$; two, sulphasalazine ( 1.5 and $3 \mathrm{~g} /$ day) and prednisolone ( 2.5 $\mathrm{mg} /$ day); one, sulphasalazine $(1 \mathrm{~g} /$ day $)$ and Colifoam enemas; and two, oral prednisolone alone ( 2.5 and 7.5 $\mathrm{mg}$ /day).

This investigation was approved by the ethical committee of St Thomas's Hospital and all patients gave informed consent.

Nutritional state was assessed as the percentage of desirable body weight for height; Metropolitan Life Assurance Company tables, and subjects below $90 \%$ desirable body weight judged to be malnourished.

Plasma zinc concentrations were determined using an IL-257 flame atomic absorption spectrophotometer (Instrumentation Laboratories). Plasma $\mathrm{C}$ reactive protein concentrations (CRP) were measured by radial immunodiffusion (Partigen plates; Behring Institute) over a range from zero to "in excess of $95 \mathrm{mg} / \mathrm{l}$ ". For statistical analysis, readings in excess of the maximum detectable-that is, $>95 \mathrm{mg} \mathrm{CRP} / 1$-were taken to be $95 \mathrm{mg} / \mathrm{l}$. Erythrocyte sedimentation rates were determined by the department of haematology, St Thomas's Hospital, and are expressed as $\mathrm{mm} /$ hour (Westergren).

Adherence was determined on samples of whole blood (containing 5 units of preservative free heparin/ $\mathrm{ml}$ blood; Leo Laboratories) by a modification of Stecher's method, ' within one hour of venepuncture. Barrels of disposable tuberculin syringes (Gillette) were packed with $20 \mathrm{mg}$ teased, scrubbed nylon fibre (Fenwal Laboratories) and compressed to the $0.1 \mathrm{ml}$ mark with the plunger. A 25 gauge needle (Becton Dickinson) was fitted and the column incubated at $37^{\circ} \mathrm{C}$ for 10 minutes. Blood $(300 \mu \mathrm{l})$ was introduced into the open end of the syringe, the plunger replaced and slowly advanced until the blood reached the bottom of the nylon fibre. The column was then incubated at $37^{\circ} \mathrm{C}$ for 10 minutes. The needle was removed to avoid subjecting the cells to shear forces and the blood expelled. Adherence was estimated by comparison of total and differential leucocyte counts $\stackrel{\vec{\rho}}{\rightarrow}$ before and after incubation. Results are expressed as $\bar{O}$ the percentage of PMN retained in the.column (mean of triplicate estimates).

PMN populations were assessed morphologically $\frac{\mathbb{Q}}{\Omega}$ by determining the average number of nuclear lobes in each cell from counts of 100 cells in blood smears. These were prepared by staining with Leishman's solution $(0.3 \% \mathrm{w} / \mathrm{v}$ in methanol; Gurr) for $20-40 \vec{\omega}$ minutes at room temperature, washing in tap water, and drying in air. Stained smears were examined by oil-immersion microscopy at $\times 1600$ magnification.

Data were compared by Wilcoxon's rank sum test $\vec{\omega}$ (PMN numbers, subpopulations, and adherence to is nylon fibre) and, for the correlation of PMN numbers, $\nexists$ CRP concentrations and erythrocyte sedimentation 옹 rates to adherence values, by least squares linear $\vec{z}$ regression analysis.

\section{Results}

All eight patients with anorexia nervosa, none of $12 \stackrel{\infty}{\circ}$ with proctocolitis, 10 of 21 with Crohn's disease, and one of 18 healthy subjects were malnourished (below $90 \%$ of desirable body weight). Median plasma zinc concentrations were slightly lower for patients with proctocolitis or those with Crohn's disease compared $\stackrel{2}{\complement}$ with healthy subjects or those with anorexia nervosa; $\stackrel{2}{\overrightarrow{\vec{A}}}$ these differences were not significant (table 2). One of $\frac{0}{3}$ nine healthy subjects, two of 11 with proctocolitis, $12 \frac{3}{5}$ of 23 with Crohn's disease, but none of the anorexia nervosa patients had detectable CRP (table 2). Nineteen of 26 patients with Crohn's disease and five of $14 \overline{8}$ with proctocolitis had ESR values in excess of the maximum detected for the healthy subjects $(16 \mathrm{~mm} / 3$. hour) (table 2).

Circulating PMN numbers were significantly higher for those patients with Crohn's $(\mathrm{p}<0.01)$ disease and 0 for those with proctocolitis $(p<0.01)$, but slightly $\rightarrow$ reduced in those with anorexia nervosa $(p>0 \cdot 1)$, compared with healthy subjects (fig la). The numbers of nuclear segments of PMN were slightly lower for all or patient groups compared with those of healthy $N$ subjects, but these differences were small (fig 1b). N

Median PMN adherence was significantly greater for patients with Crohn's disease $(\mathrm{p}<0.01)$ and those ${ }_{0}$ with proctocolitis $(p<0.05)$, but lower in those with $\frac{D}{\Phi}$ anorexia nervosa, compared with that of healthy subjects (fig 2). Fourteen of 25 with Crohn's disease $\frac{7}{T}$ and two of 10 with proctocolitis had adherence values $\vec{O}$ in excess of the maximum value (77\% PMN adherent) $\stackrel{\vec{Q}}{\stackrel{\oplus}{Q}}$ for healthy subjects. The data for these 14 patients $\stackrel{\mathbb{Q}}{\varrho}$ with Crohn's disease were therefore analysed further. 
Table 2 Plasma zinc and C reactive protein (CRP) concentrations, and erythrocyte sedimentation rates (ESR)

\begin{tabular}{|c|c|c|c|c|c|c|c|c|c|}
\hline & \multicolumn{3}{|c|}{ Plasma zinc $(\mu \mathrm{g} / \mathrm{ml})$} & \multicolumn{3}{|c|}{$C R P(m g / l)$} & \multicolumn{3}{|c|}{ ESR (mm/hour, Westergren) } \\
\hline & $(n)$ & Median & Range & $(n)$ & Median & Range & $(n)$ & Median & Range \\
\hline $\begin{array}{l}\text { Healthy subjects } \\
\text { Crohn's disease } \\
\text { Ulcerative proctocolitis } \\
\text { Anorexia nervosa }\end{array}$ & $\begin{array}{r}(17) \\
(29) \\
(10) \\
(8)\end{array}$ & $\begin{array}{l}0.97 \\
0.88 \\
0.86 \\
0.96\end{array}$ & $\begin{array}{l}0.88-1 \cdot 22 \\
0 \cdot 67-1 \cdot 20 \\
0 \cdot 70-1 \cdot 05 \\
0 \cdot 76-1 \cdot 13\end{array}$ & $\begin{array}{l}(9) \\
(23) \\
(11) \\
(10)\end{array}$ & $\begin{array}{l}0 \\
4 \\
0 \\
0\end{array}$ & $\begin{array}{l}0-11.8 \\
0->95^{*} \\
0-73 \\
0\end{array}$ & $\begin{array}{l}(8) \\
(26) \\
\text { NR }\end{array}$ & $\begin{array}{c}4 \\
24 \\
8 \cdot 5 \\
\text { NR }\end{array}$ & $\begin{array}{l}1-16 \\
3-74^{*} \\
3-45 \dagger \\
\text { NR }\end{array}$ \\
\hline
\end{tabular}

${ }^{*} \mathrm{p}<0.01 v$ healthy subjects.

$+\mathrm{p}<0.05 v$ healthy subjects.

NR, not recorded.
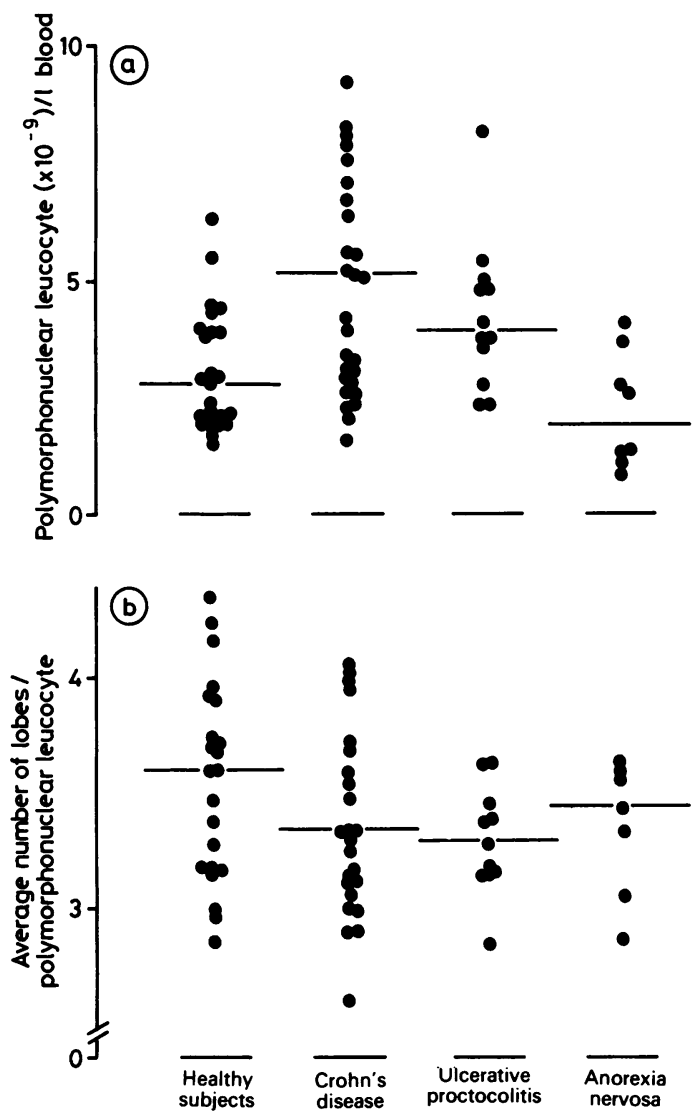

Fig 1 (a) Numbers of polymorphonuclear leucocytes in blood of subject groups studied (median and individual values are indicated (Crohn's disease and ulcerative proctocolitis $v$ healthy subjects $p<0.01)$. (b) Average numbers of nuclear lobes polymorphonuclear leucocytes (median values are indicated).

Within this group (table 3) the proportions of patients with active Crohn's disease $(69 \%$, nine of 13$)$ or receiving treatment $(62 \%)$ were not significantly different from those with normal adherence values (50\% and $58 \%$, respectively). Malnutrition was twice as common among those with high adherence values

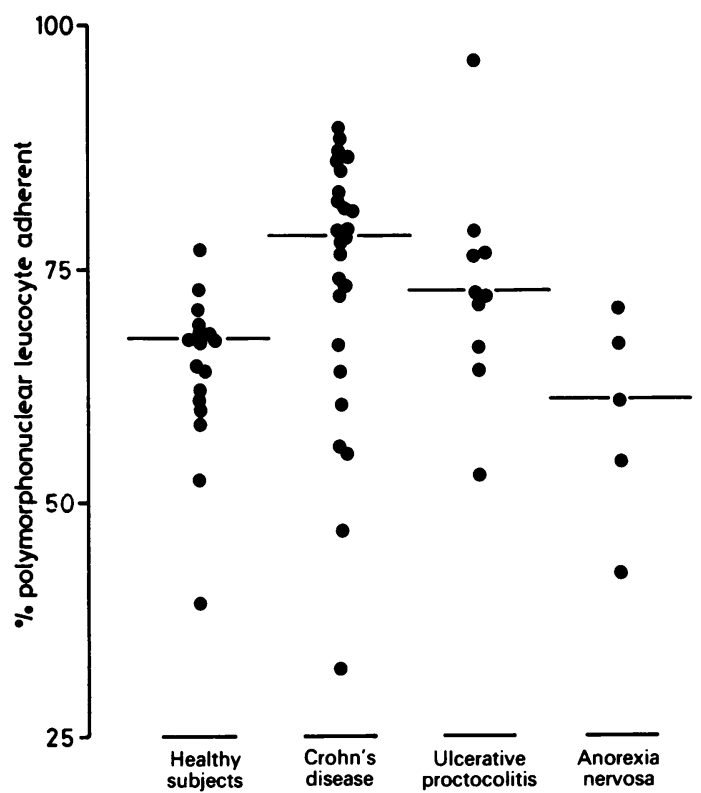

Fig 2 Percentage of blood polymorphonuclear leucocytes adherent to nylon fibre for patients with Crohn's disease, ulcerative proctocolitis, anorexia nervosa, and healthy subjects. Median and individual values are shown (Crohn's disease $v$ healthy subjects $p<0.01$ : ulcerative proctocolitis $v$ healthy subjects $p<0.05)$.

(54\%) compared with the remainder (25\%). Overall, however, PMN adherence values for the malnourished $(\mathrm{n}=10$, median adherence $80 \%$, range $64-89 \cdot 5 \%$ ) and normally nourished ( $\mathrm{n}=11$, median $77.5 \%$, range $55 \cdot 5-88 \cdot 5 \%$ ) patients with Crohn's disease did not differ significantly.

PMN adherence values for the patients with Crohn's disease did not parallel their numbers of circulating PMN (fig 3). Furthermore, eight of 10 patients with Crohn's disease with detectable plasma CRP also had adherence values in excess of the maximum for healthy subjects; there was no simple association between absolute concentrations of CRP and PMN adherence values (fig $4 \mathrm{a}$ ). Similarly, there 
Table 3 Clinical details of patients with Crohn's disease with adherence values in excess of maximum detected for healthy subjects (77\% PMN adherence)

\begin{tabular}{|c|c|c|c|}
\hline $\begin{array}{l}\text { Case } \\
\text { No }\end{array}$ & $\begin{array}{l}\text { CDAI } \\
\text { score }\end{array}$ & $\begin{array}{l}\text { Percentage } \\
\text { of desirable } \\
\text { body weight }\end{array}$ & $\begin{array}{l}\text { Drug } \\
\text { regimen }\end{array}$ \\
\hline $\begin{array}{l}\text { SM } \\
\text { GP } \\
\text { FD } \\
\text { RB }\end{array}$ & $\begin{array}{l}471 \\
455 \\
132 \\
168\end{array}$ & $\begin{array}{l}85 \cdot 2 \\
79 \cdot 7 \\
79 \cdot 6 \\
97 \cdot 3\end{array}$ & $\begin{array}{l}\text { Prednisolone } \\
\text { Sulphasalazine } \\
0 \\
\text { Sulphasalazine and } \\
\text { prednisolone }\end{array}$ \\
\hline $\begin{array}{l}\text { JA } \\
\mathbf{L N}\end{array}$ & $\begin{array}{l}243 \\
343\end{array}$ & $\begin{array}{r}98 \cdot 5 \\
122 \cdot 2\end{array}$ & $\begin{array}{l}\text { Sulphasalazine } \\
\text { Adrenocorticotrophic } \\
\text { hormone }\end{array}$ \\
\hline $\begin{array}{l}\text { AD } \\
\text { LB } \\
\text { HL } \\
\text { GR } \\
\text { JO } \\
\text { IM } \\
\text { Mc } \\
\text { LK }\end{array}$ & $\begin{array}{l}300 \\
99 \\
104 \\
226 \\
208 \\
140 \\
\text { Not recorded } \\
247\end{array}$ & $\begin{array}{l}86 \cdot 8 \\
85 \cdot 1 \\
98 \cdot 1 \\
72 \cdot 6 \\
92 \cdot 7 \\
72 \cdot 2 \\
\text { Not recorded } \\
90 \cdot 2\end{array}$ & $\begin{array}{l}0 \\
\text { Sulphasalazine } \\
0 \\
0 \\
\text { Sulphasalazine } \\
\text { Prednisolone } \\
\text { Not recorded } \\
0\end{array}$ \\
\hline
\end{tabular}

CDAI, Crohn's disease activity index
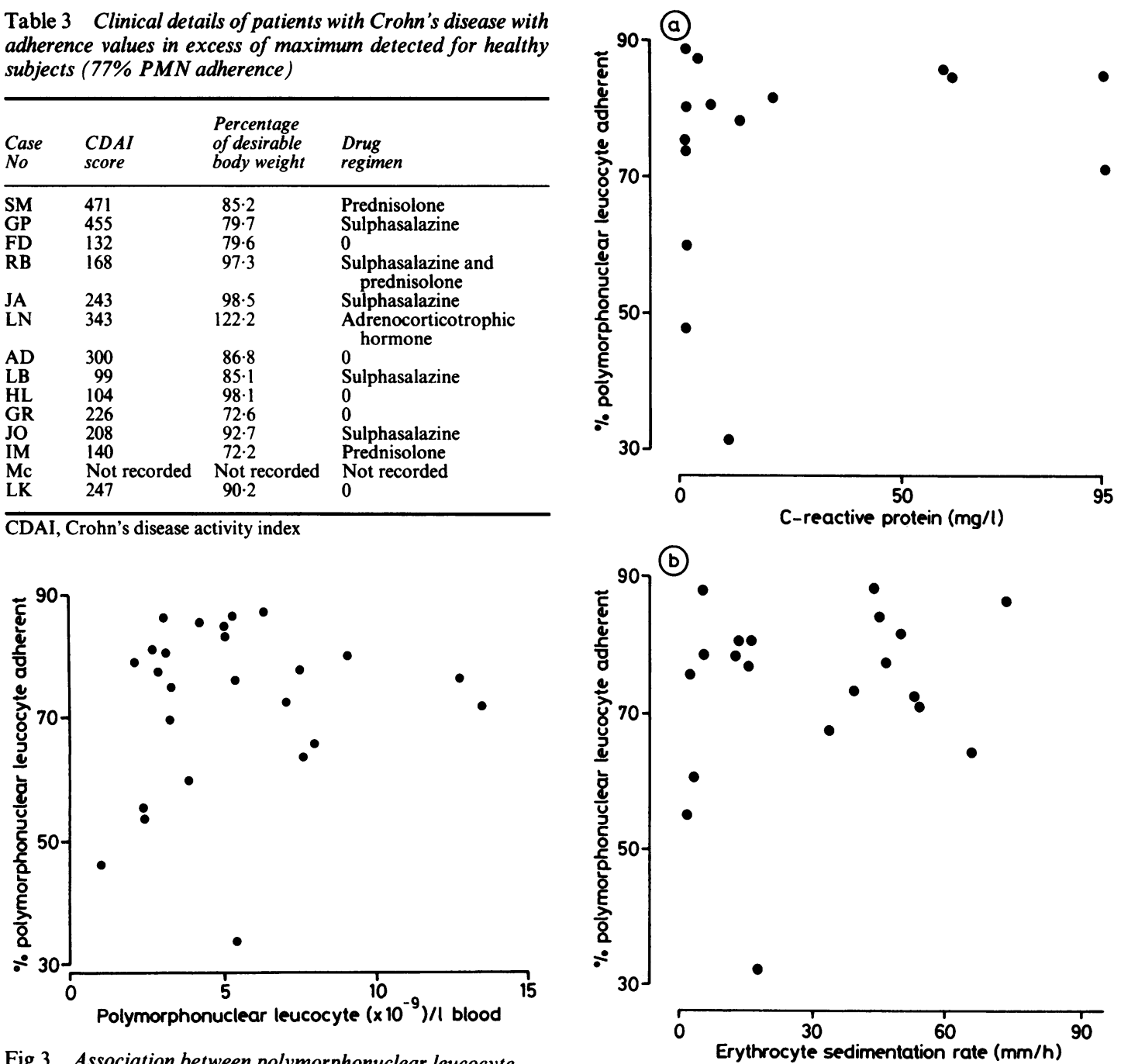

Fig 3 Association between polymorphonuclear leucocyte adherence and numbers in blood for patients with Crohn's disease $(r=0 \cdot 16 ; p>0 \cdot 1)$.

was no apparent association between ESR values and PMN adherence for patients with Crohn's disease: indeed, only five of the 20 patients assessed had the combination of an ESR and a PMN adherence value that was in excess of the respective maximum value for healthy subjects (fig $4 b$ ).

\section{Discussion}

PMN adhesiveness to nylon fibre was high for some patients with Crohn's disease and a few with ulcerative proctocolitis compared with that found in healthy subjects. Enhanced PMN adhesiveness also occurs in

Fig 4 (a) Association between polymorphonuclear leucocyte adherence values and $C$ reactive protein concentrations for patients with Crohn's disease ( $r=0 \cdot 209$; $p>0 \cdot 1)$. (b) Association between polymorphonuclear leucocyte adherence values and erythrocyte sedimentation rates for patients with Crohn's disease $(r=0 \cdot 204, p>0 \cdot 1)$.

alcoholic cirrhosis, ${ }^{2}$ rheumatoid arthritis, ${ }^{3}$ systemic $\stackrel{0}{\circ}$ lupus erythematosus, vasculitis and pneumonia ${ }^{4}$ and $\mathscr{\Phi}$ may represent a change that accompanies episodes of ? acute inflammation. Some of the beneficial effects of glucocorticoids in inflammatory bowel disease may be $\underset{\mathbb{D}}{\circ}$ due to their ability to reduce PMN adherence. ${ }^{14}$

Although previous studies have found evidence of $\stackrel{\mathbb{Q}}{\varrho}$ impaired PMN function in Crohn's disease, ${ }^{15}$ more 
recent studies suggest that PMN play an active part in acute episodes: there is a pronounced migration of $\mathrm{PMN}$ to affected regions. ${ }^{16} \mathrm{~A}$ raised adherence may facilitate the margination and migration of PMN to the base of ulcers in Crohn's disease and the mucosa in proctocolitis. ${ }^{17}$ High adherence has sometimes been associated with chemotactic unresponsiveness ${ }^{18}$; the present results may alternatively explain the overall paucity of PMN in the gut wall of Crohn's diseaseapart from at sites of ulceration. ${ }^{19}$ Such a failure of the PMN response might account for the incomplete removal of any putative antigenic material and predispose to granuloma formation. ${ }^{20}$

The adhesiveness of PMN to nylon fibre is often comparable with their adhesiveness to cultured endothelial cells. ${ }^{21}$ The adhesiveness to endothelial cells, however, may be influenced by other factors such as the elaboration of mediators from both cell types. ${ }^{22}$ In addition, interaction of these cells depends on the CDw18 PMN membrane complex ${ }^{23}$ : genetic deficiency of the CDw18 glycoprotein MO1 causes defective PMN adherence to inert materials such as glass ${ }^{24-29}$ or to endothelial cells, ${ }^{25} 3031$ PMN-PMN aggregation, ${ }^{27-29}$ and severe infections in childhood. Thus there is no reason to suspect that the simplicity of the assay system used in the present study detracts from its validity in assessing PMN adhesiveness.

Functional, ${ }^{32}$ morphological, ${ }^{33}$ and numerical changes of circulating PMN occur during acute infection and these may affect PMN adherence. According to morphological criteria used in the present study, however, PMN were normal in Crohn's disease-in accordance with the findings of other reports. ${ }^{34}$ While many patients with Crohn's disease had PMN leucocytosis this was not related to raised adherence values.

Alternatively, high adherence of PMN may represent cellular activation by soluble factors in sera from patients with Crohn's disease. ${ }^{5}$ These substances may include the complement component $\mathrm{C} 5 \mathrm{a}^{35}$ and circulating immune complexes, ${ }^{36}$ which both activate PMN and enhance their adhesiveness. Immune complexes can be detected in the sera of patients with Crohn's disease ${ }^{37}{ }^{38}$ and also in or on their PMN, but their presence does not always correlate with PMN adherence values. ${ }^{5}$ Another possibility is that acute phase proteins modulate the adhesiveness of PMN. While CRP was detected in many of the plasmas from those patients with Crohn's disease with supranormal PMN adherence values, absolute values for plasma CRP and PMN adherence were not statistically associated. Furthermore, high PMN adherence did not correlate positively with erythrocyte sedimentation rates nor with assessments of disease severity for patients with Crohn's disease. These observations may be due to temporal differences between the changes in
PMN adherence and clinical or biochemical features of disease.

Other aspects of inflammatory bowel disease may affect PMN adhesiveness, but neither drug treatment nor zinc depletion explained the present results. Interestingly, malnourished patients with Crohn's disease tended to have slightly greater adherence values than those who were normally nourished, yet those with anorexia had reduced values. This disparity may be due to the differing types of malnutrition in these two conditions, or may reflect an association between malnutrition and severe or prolonged Crohn's disease. Although low plasma zinc concentrations may occur in Crohn's disease, ${ }^{10}{ }^{11}$ true tissue zinc deficiency is unusual (CC Ainley, J Cason, and RPH Thompson, unpublished observations). The low plasma zinc concentrations in some patients with Crohn's disease probably reflect the cumulative effects of low albumin concentrations and acute phase changes rather than being a true deficiency.

Several of the present observations (PMN leucocytosis; detectable plasma CRP; low zinc concentrations) may be due to the biological activities of interleukin-1 (IL-1). Indeed, mononuclear cells from some patients with Crohn's disease and also, but less commonly, from patients with proctocolitis, release an IL-1 activity (lymphocyte activating factor) without exogenous stimulation in vitro. ${ }^{390}$ This is perhaps caused by endotoxinaemia, which is often associated with active disease. ${ }^{41}$

In conclusion, PMN adhesiveness to nylon fibre is high in many patients with inflammatory bowel disease, particularly those with Crohn's disease. This abnormality was not explained by differences of circulating PMN populations, and was not related to CRP concentration, ESR values, drug regimen, malnutrition, zinc depletion, or disease severity.

This work was presented in part to the British Society for Immunology, November 1985. We are grateful for support from the Samuel Thomas Johnson Foundation (JC), the Wellcome Trust (CCA), and the Special Trustees of St Thomas's Hospital.

\section{References}

1 Stecher V, Chinea GL. The neutrophil adherence assay as a means of detecting unique anti-inflammatory agents. Agents and Actions 1978;8:258-62.

2 Altin M, Rajkovic LA, Hughes RD, Williams R. Neutrophil adherence in chronic liver disease and fulminant hepatic failure. Gut 1983;24:746-50.

3 Lentnek AL, Schreiber AD, MacGregor RR. The induction of an augmented granulocyte adherence by inflammation mediation by a plasma factor. J Clin Invest 1976;57:1098-103.

4 Malech HL, Root RK, Gallin JI. Structural analysis of neutrophil migration. J Cell Biol 1977;75:666-93.

5 Kirk AP, Cason J, Fordham JN, et al. Polymorphonuclear 
leucocyte function in ulcerative colitis and Crohn's disease. Dig Dis Sci 1983;28:236-48.

6 MacGregor RR. Granulocyte adherence changes induced by haemodialysis, endotoxin, epinepherine and glucocorticoids. Ann Intern Med 1977;86:35-9.

7 Ketts DG, Grand RJ, Shen G, Watkins JB, Werlin SL, Boehme C. Nutritional basis of growth failure in children and adolescents with Crohn's disease. Gastroenterology 1979;76:720-7.

8 Gerson CD, Cohen N, Janowitz HD. Small intestinal absorption in regional enteritis. Gastroenterology 1973;64:907-12.

9 Beeken WL, Busch MJ, Sylwester DL. Intestinal protein loss in Crohn's disease. Gastroenterology 1972;62:207-15.

10 Solomons NW, Rosenberg IH, Sandstead HH, Vo-Khactu KP. Zinc deficiency in Crohn's disease. Digestion 1977;16:87-95.

11 Sturnoib GC, Molokhia MM, Sheilds RV, Turnberg LA. Zinc absorption in Crohn's disease,. Gut 1980;21:387-91.

12 Best WR, Becktel JM, Singleton JW, Kern F. Development of a Crohn's disease activity index, National Cooperative Crohn's disease study. Gastroenterology 1976;70:439-44.

13 Truelove SC, Witts LJ. Cortisone in ulcerative colitis. Br Med J 1955;ii:1041-8.

14 MacGregor RR, Spagnuolo PJ, Letnek AL. Inhibition of granulocyte adherence by ethanol, prednisolone and aspirin, measured with an assay system. $N$ Engl J Med 1974;291:642-6.

15 Hermanowicz A, Gibson PR, Jewell DP. The role of phagocytes in inflammatory bowel disease. Clin Sci 1985;69:241-9.

16 Saverymuttu SH, Peters AM, Lavender JP, Chadwick VS, Hodgson HJF. In vivo assessment of granulocyte migration to diseased bowel in Crohn's disease. Gut 1985;26:378-83.

17 Gebbers JO, Otto HF. Immunohisto- and ultracytochemical observations on early lesions of ulcerative colitis. Gut 1978;19:A989.

18 Fehr J, Dahinden G. Modulating influence of chemotactic factor induced cell adhesiveness on granulocyte function. J Clin Invest 1979;64:8-16.

19 O'Connor JJ. An electron microscope study of inflammatory colonic disease. Dis Colon Rectum 1972;15:265-77.

20 Ward M. Pathogenesis of Crohn's disease. Lancet 1977;ii:903-5.

21 MacGregor RR, Macorac EJ, Ketalides NA. Comparative adherence of granulocytes to endothelial monolayers and nylon fibres. J Clin Invest 1978;61:697-702.

22 Zimmerman GA, Wiseman GA, Hill HR. Human endothelial cells modulate granulocyte adherence and chemotaxis. J Immunol 1985;134:1866-74.

23 Pohlman TH, Stannes KA, Beatty PG, Ochs HD, Harlan JM. An endothelial cell surface factor(s) induced in vitro by lipopolysaccharide, interleukin- 1 and tumor necrosis factor increases neutrophil adherence by a CDw18 dependent mechanism. $J$ Immunol 1986;136:4548-53.

24 Anderson DC, Schmalsteig FC, Arnaout MA, et al. Abnormalities of polymorphonuclear leucocyte function associated with a heritable deficiency of high molecular weight surface glycoproteins (GP 138): common relationship to diminished cell adherence. J Clin Invest 1984;74:536-51.

25 Bowen TJ, Ochs HD, Altman LC, et al. Severe recurrent bacterial infections associated with defective adherence and chemotaxis in two patients with neutrophils deficient in a cell-associated glycoprotein. J Paeditar 1982;101:932-40.
26 Fischer A, Deschamps-Latscha B, Gasta I, et al. Bone marrow transplantation for inborn error of phagcytic cells associated with defective adherence, chemotaxis and oxidative response during opsonized particle phagocytosis. Lancet 1983;ii:473.

27 Buescher ES, Gaither T, Nath J, Gallin JI. Abnormal adherencerelated functions of neutrophils and monocytes and EpsteinBarr virus transformed B-cells in a patient with C3bi receptor deficiency. Blood 1981;65:1382-6.

28 Arnout MA, Pitt J, Cohen HJ, Melamed J, Rosen FS, Colten HR. Deficiency of a granulocyte-membrane glycoprotein (GP 150) in a boy with recurrent bacterial infections. $N$ Engl $J$ Med 1982;306:693-9.

29 Anderson DC, Schmalsteig FC, Shearer W, et al. Leukocyte LFA1, OKM1, p150,95 deficiency syndrome: functional and biosynthetic studies of three kindreds. Fed Proc 1985;44:2671-7.

30 Schwartz BR, Ochs HD, Beatty PG, Harlan JM. A monoclonal antibody-defined membrane antigen complex is required for neutrophil-neutrophil aggregation. Blood 1985;65:1553-6.

31 Beatty PG, Ochs HD, Harlan JM, et al. Absence of a monoclonal antibody defined protein complex in a boy with abnormal leukocyte function. Lancet 1984; i:535-7.

32 Bass DA, Olbantz P, Szejda P, Seeds MC, McCall CE. Subpopulations of neutrophils with increased oxidative product formation in the blood of patients with infection. $J$ Immunol 1986;136:860-6.

33 Documenta Geigy. Synopsis of blood-leukocytes. Geigy, 1962:561.

34 Wandall JH, Binder V. Leucocyte function in Crohn's disease. Gut 1982;23:173-80.

35 Craddock PR, Hammerschmidt D, White TG, Dalmasso AP, Jacob HS. Complement (C5a) induced granulocyte aggregation in vitro-a possible mechanism of complement mediated leucostasis and leucopenia. J Clin Invest 1970;60:260-4.

36 Wilkinson PC, Lackie JM. The adhesion, migration and chemotaxis of leucocytes in inflammation. Curr Top Pathol 1979;68:47-88.

37 Lurhuma AZ, Cambiasco CL, Mason PL, Heremanns JF. Detection of circulating antigen-antibody complexes by their inhibitory effect on the agglutination of IgG coated particles by rheumatoid factor of Clq. Clin Exp Immunol 1976;25:212-26.

38 Danis VA, Harries AD, Heatly RV. Antigen-antibody complexes in inflammatory bowel disease. Scand $J$ Gastroenterol 1984;19:603-6.

39 Satsangi J, Wolstencroft RA, Cason J, Ainley CC, Dumonde DC, Thompson RPH. Interleukin-1 in Crohn's disease. Clin Exp Immunol 1987;67:594-605.

40 Hubbard RB, Punchard NA, Cason J, et al. Interleukin-1, prostaglandin E2 and trace metals in ulcerative colitis. Clin Sci 1987;72:1-50.

41 Wellmann W, Fink PC, Benner F, Schmidt FW. Endotoxaemia in active Crohn's disease. Treatment with whole gut irrigation and 5-aminosalicyclic acid. Gut 1986;27:814-20.

Requests for reprints to: $\mathrm{Mr} \mathrm{J}$ Cason, Laboratory of Cancer, Department of Virology, The Rayne Institute, St Thomas's Hospital, London SE1 7EH, England. 